\title{
FAKTOR-FAKTOR YANG BERHUBUNGAN DENGAN PERILAKU MASYARAKAT DALAM PENCEGAHAN COVID-19 DI WILAYAH KERJA PUSKESMAS KENALI BESAR KECAMATAN ALAM BARAJO
}

\author{
Okta Putri Mayasari, Ikalius, Wahyu Indah Dewi Aurora \\ Fakultas Kedokteran Dan Ilmu Kesehatan Univeritas Jambi \\ Corresponding author email: oktaputrimayasari10@gmail.com
}

\begin{abstract}
The continuous increase in Covid-19 cases requires efforts to break the chain of the spread of Covid-19, one must be able to maintain personal health. In maintaining one's health, there are two main factors, namely behavior and non-behavior. According to $L$. Green behavior is determined by three factors, namely predisposing factors including age, occupation, education, knowledge and attitudes. The purpose of this study is to determine the factors related to community behavior with efforts to prevent Covid-19 in the work area of the Kenali Besar Community Health Center, Alam Barajo District. This study was an analytic observational study, cross sectional design, with the chi-square test. Sampling technique Accidental sampling. The results of the analysis show that the variables of age, knowledge, attitudes with Covid-19 prevention behavior in communities in the working area of the Kenali Besar Alam barajo Community Health Center. With a $P$-value of 0.501 for age, a $p$-value of 0.203 for education, a $P$-value of 0.320 for knowledge, a P-value of 0.466 for attitudes. There was no significant relationship between age, education, knowledge, and attitudes with Covid-19 prevention behavior. the working area of the Kenali Besar Community Health Center, Alam Barajo District.
\end{abstract}

Keywords: Age, Education, Knowledge, Behavior

\section{ABSTRAK}

Peningkatnya kasus Covid-19 yang terus menerus memerlukan upaya pemutusan mata rantai penyebaran Covid-19, seseorang harus mampu menjaga kesehatan diri. Dalam menjaga kesehatan seseorang, terdapat dua faktor pokok yaitu perilaku dan non perilaku. Menurut L.Green prilaku ditentukan oleh tiga faktor yaitu faktor predisposisi meliputi umur, pekerjaan, pendidikan, pengetahuan dan sikap.Tujuan penelitian ini mengetahui faktor-faktor berhubungan dengan prilaku masyarakat dengan usaha pencegahan Covid-19 di wilayah kerja puskesmas Kenali Besar Kecamatan Alam Barajo. Penelitian ini adalah penelitian observasional analitik, rancangan cross sectional, dengan uji chi-square. Teknik pengambilan sampel Accidental sampling. Hasil analisis menunjukkan bahwa variabel usia, pengetahuan, sikap dengan prilaku pencegahan Covid-19 pada Masyarakat di wilayah kerja Puskesmas Kenali Besar Alam barajo. Dengan $P$ value 0,501 utnuk usia, $p$-value 0,203 untuk pendidikan, $P$-value 0,320 untuk pengetahuan, $P$-value 0,466 untuk sikap.Tidak terdapat hubungan bermakna antara Usia, Pendidikan, Pengetahuan, dan Sikap dengan Prilaku pencegahan Covid-19 Masyarakat pada wilayah kerja Puskesmas Kenali Besar Kecamatan Alam Barajo.

Kata Kunci: Umur, Pendidikan, Pengetahuan, Prilaku 


\section{PENDAHULUAN}

Dunia hingga kini dihadapkan pada persoalan menyebarnya virus baru yang dinamai Corona Virus Disease 2019 (COVID-19), atau yang dikenal juga dengan Severe Acute Respiratory Syndrome Coronavirus 2 (SARS-CoV-2). ${ }^{1}$ Kasus ini pertama kali ditemukan di Wuhan Provinsi Hubei Tiongkok pada awal Desember 2019 dengan seorang pasien didiagnosis menderita pneumonia yang tidak biasa. Pada 31 Desember, kantor regional organisasi kesehatan dunia (WHO) di Beijing telah menerima pemberitahuan tentang sekelompok pasien dengan pneumonia yang tidak diketahui penyebabnya dari kota yang sama. ${ }^{2}$

WHO pertama kali menetapkan status pandemi global pada tanggal 11 Maret 2020 disebabkan virus ini telah menyebar ke berbagai negara di dunia. ${ }^{3}$ Dilaporkan kasus Covid-19 pada tanggal 11 Desember 2020 menurut World Health Organization terdapat 68 juta kasus Covid19 yang terkonfirmasi, dengan jumlah tertinggi di Amerika diikuti Eropa sedangkan Asia berada diurutan ketiga, dengan jumlah kematian mencapai 1 juta kasus. ${ }^{4}$ Indonesia pertama kali mengkonfirmasi kasus Covid19 pada tanggal 2 Maret 2020 dengan penemuan kasus sebanyak dua kasus terkonfirmasi. ${ }^{5}$ Kasus di Indonesia terus mengalami peningkatan sampai dengan tanggal 11 Desember 2020 sebanyak 605.243 kasus terkonfirmasi dengan jumlah kasus kematian sebanyak 18.511 kasus. Beberapa Provinsi di Indonesia dilaporkan tanggal 11 Desember 2020 dengan jumlah kasus tertinggi yaitu DKI Jakarta dengan
150.250 kasus, Jawa Timur 68.361 kasus dan Jawa Tengah 64.608 kasus. $^{6}$ Sedangkan untuk Provinsi Jambi sendiri pada tanggal 11 Desember 2020 sebanyak 2.573 kasus terkonfirmasi, dengan kasus tertinggi Kota Jambi sebanyak 846 kasus terkonfirmasi. $^{7}$ Sedangkan untuk kecamatannya itu sendiri pada 3 bulan terakhir kasus tertinggi berada pada kecamatan Alam Barajo sebanyak 18 kasus. $^{8}$

Beradasarkan bukti ilmiah, Covid19 dapat menular dari manusia melalui kontak erat dan droplet, tidak melalui udara. Orang yang paling beresiko tertular penyakit ini adalah orang yang kontak erat dengan pasien Covid-19 termasuk yang merawat pasien Covid-19. ${ }^{9}$ Untuk meminimalisir korban, pemerintah telah menggalakkan berbagai upaya, diantaranya adalah dengan mensosialisasikan social distancing yaitu pembatasan sosial kemudian diperketat lagi dengan physical distancing atau menjaga jarak fisik dari orang lain. Himbauan mencuci tangan dengan sabun, hand sanitizer serta memakai masker, bekerja, sekolah, dan beribadah dirumah, dan terakhir dilakukannya kebijakan Pembatasan Sosial Berskala Besar (PSBB) oleh pemerintah, namun hingga saat ini belum mampu memutus atau memperlambat penyebaran Covid 19 ini. ${ }^{10}$

Upaya pemutusan mata rantai penyebaran Covid-19, seseorng harus mampu menjaga kesehatan diri. Dalam menjaga kesehatan seseorang terdapat dua faktor pokok yaitu perilaku dan non perilaku. ${ }^{11}$ Menurut L.Green prilaku ditentukan oleh tiga faktor yaitu faktor 
predisposisi (Predisposing Factors) yang meliputi umur, pekerjaan, pendidikan, pengetahuan dan sikap, faktor pemungkin (Enabling Factors) yang terwujud dalam lingkungan fisik dan jarak ke fasilitas kesehatan, dan faktor penguat (Reinforcing Factors) yang terwujud dalam dukungan yang diberikan oleh keluarga maupun tokoh masyarakat. ${ }^{12}$ Penelitian ini bertujun untuk melihat faktor-faktor apa saja yang mempengaruhi prilaku masyarakat dengan usaha pencegahan penularan Covid-19 di wilayah kerja Puskesmas Kenali Besar Kecamatan Alam Barajo.

\section{METODE}

Penelitian merupakan penelitian observasional analitik, rancangan cross sectional dianalisis dengan uji chi-square., penelitian ini di lakukan pada bulan Februari 2020 di wilayah kerja Puskesmas Kenali Besar Kecamatan Alam Barajo. Jaumlah sampel dalam penelitian ini 91 orang. Teknik sampling untuk penelitian ini menggunakan Accidental sampling yang memenuhi kriteria inklusi. Pengumpulan data yang dilakukan dalam penelitian menggunakan kuesioner telah melalui uji validitas dan reabilitas.

\section{HASIL DAN PEMBAHASAN}

Hasil penelitian disajikan dalam bentuk tabel yang terdiri data analisis bivariat.
Tabel 1. Analisis Bivariat Usia dan Perilaku Pencegahan Covid-19

\begin{tabular}{lllllllll}
\hline Usia & \multicolumn{2}{l}{$\begin{array}{l}\text { Perilaku } \\
\text { buruk }\end{array}$} & \multicolumn{2}{l}{$\begin{array}{l}\text { Perilaku } \\
\text { baik }\end{array}$} & & Total & $\begin{array}{l}P \\
\text { value }\end{array}$ \\
\hline & $\mathrm{n}$ & $\%$ & $\mathrm{~N}$ & $\%$ & $\mathrm{n}$ & $\%$ & \\
\cline { 2 - 7 } $\begin{array}{l}\text { Dewasa } \\
\text { Awal }\end{array}$ & 11 & 16,4 & 56 & 83,6 & 67 & 100 & 0,501 \\
$\begin{array}{l}\text { Dewasa } \\
\text { Madya }\end{array}$ & 2 & 8,3 & 22 & 91,7 & 24 & 100 & \\
\hline
\end{tabular}

Berdasarkan tabel 1 diketahui responden untuk kategori usia dewasa awal dengan perilaku buruk sebesar 11 orang $(16,4 \%)$, dan terdapat 56 orang $(83,6 \%)$ dengan perilaku baik. Sedangkan pada kategori usia dewasa madya dengan perilaku buruk sebesar 2 orang $(8,3 \%)$, dan terdapat 22 orang $(91,7 \%)$ dengan perilaku baik.

Tabel 2. Analisis Bivariat Pendidikan dan Perilaku Pencegahan Covid-19

\begin{tabular}{cccccccc}
\hline Pendidikan & $\begin{array}{c}\text { Perilaku } \\
\text { buruk }\end{array}$ & \multicolumn{2}{c}{$\begin{array}{c}\text { Perilaku } \\
\text { baik }\end{array}$} & Total & $\begin{array}{c}P \\
\text { value }\end{array}$ \\
\hline & $\mathrm{n}$ & $\%$ & $\mathrm{~N}$ & $\%$ & $\mathrm{~N}$ & $\%$ & \\
\cline { 2 - 6 } $\begin{array}{c}\text { Pendidikan } \\
\text { rendah } \\
\begin{array}{c}\text { Pendidikan } \\
\text { tinggi }\end{array}\end{array}$ & 11 & 33,3 & 4 & 66,7 & 6 & 100 & 0,203 \\
\hline
\end{tabular}

Berdasarkan tabel 2 diketahui responden untuk kategori Pendidian rendah dengan perilaku buruk sebesar 2 orang $(33,3 \%)$, dan terdapat 4 orang $(66,7 \%)$ dengan perilaku baik. Sedangkan pada kategori pendidikan tinggi dengan perilaku buruk sebesar 11 orang (12,9\%), dan terdapat 74 orang $(87,1 \%)$ dengan perilaku baik. 
Tabel 3 Analisis Bivariat Pengetahuan dan Perilaku Pencegahan Covid-19

\begin{tabular}{|c|c|c|c|c|c|c|c|}
\hline \multirow[t]{2}{*}{ Pengetahuan } & \multicolumn{2}{|c|}{$\begin{array}{c}\text { Perilaku } \\
\text { buruk }\end{array}$} & \multicolumn{2}{|c|}{$\begin{array}{c}\text { Perilaku } \\
\text { baik }\end{array}$} & \multicolumn{2}{|c|}{ Total } & \multirow{2}{*}{$\begin{array}{c}P \\
\text { valu } \\
e\end{array}$} \\
\hline & $\mathrm{n}$ & $\%$ & $\mathrm{~N}$ & $\%$ & $\mathrm{~N}$ & $\%$ & \\
\hline Pengetahuan & 2 & 25,0 & 6 & 75,0 & 8 & 10 & 0,32 \\
\hline buruk & & & & & & 0 & 0 \\
\hline Pengetahuan & 8 & 13,3 & 72 & 86,7 & 83 & 10 & \\
\hline baik & & & & & & 0 & \\
\hline
\end{tabular}

Berdasarkan tabel 3 diketahui responden untuk kategori Pengetahuan buruk dengan perilaku buruk sebesar 2 orang $(25,0 \%)$, dan terdapat 6 orang $(75,0 \%)$ dengan perilaku baik. Sedangkan pada kategori pengetahuan baik dengan perilaku buruk sebesar 8 orang (13,3\%), dan terdapat 72 orang $(86,7 \%)$ dengan perilaku baik.

Tabel 4 Analisis Bivariat Sikap dan

Perilaku pencegahn Covid-19

\begin{tabular}{lccccccc}
\hline Sikap & $\begin{array}{c}\text { Perilaku } \\
\text { buruk }\end{array}$ & $\begin{array}{c}\text { Perilaku } \\
\text { baik }\end{array}$ & Total & $\begin{array}{c}P \\
\text { valu } \\
\end{array}$ \\
\cline { 2 - 6 } & $\mathrm{n}$ & $\%$ & $\mathrm{n}$ & $\%$ & $\mathrm{n}$ & $\%$ & \\
\cline { 2 - 6 } $\begin{array}{l}\text { Sikap } \\
\text { buruk }\end{array}$ & 1 & 25 & 3 & 75 & 4 & 10 & 0,46 \\
Sikap & 1 & 13,8 & 7 & 86, & 8 & 10 & \\
baik & 2 & & 5 & 2 & 7 & 0 & \\
\hline
\end{tabular}

Berdasarkan tabel 4 diketahui responden untuk kategori Sikap buruk dengan perilaku buruk sebesar 1 orang (25\%), dan terdapat 3 orang $(75 \%)$ dengan perilaku buruk. Sedangkan pada kategori sikap baik dengan prilaku buruk sebesar 12 orang $(13,8 \%)$, dan terdapat 75 orang $(86,2 \%)$ dengan prilaku baik.

\section{PEMBAHASAN}

Dengan bertambahnya usia, tubuh akan mengalami berbagai penurunan akibat proses penuaan, hampir semua fungsi organ dan gerak menurun, diikuti dengan menurunnya imunitas sebagai pelindung tubuh pun tidak bekerja sekuat ketika masih muda, menurut $\mathrm{F}$ Caramelo dkk usia di atas 60 tahun paling besar beresiko terkena Covid-19 yaitu berkisar 18,8 kali lebih besar dibandingkan usia di bawah 60 tahun dan semangkin meningkat dengan penyakit penyerta. ${ }^{13}$ WHO dan CDC melaporkan bahwa pada usia pra-lansia 50-59 tahun angka kematian hampir 2\%, usia 60-69 tahun $4 \%$, terus naik menjadi 8 sampai $15 \%$ pada usia diatas 70 tahun. ${ }^{14}$ Oleh karena itu sebaiknya dilakukan pencegahan sedini mungkin pada segala kelompok usia terutama pada usia lanjut.

Pada penelitian ini diperoleh hasil bahwa tidak ada hubungan yang bermakna antara usia dengan prilaku pencegahan covid-19 dengan nilai $P$ sebesar 0,501 $(P>0,05)$. Hal serupa didapatkan dari penelitian Prihati dkk, penelitian tersebut menyatakan bahwa tidak terdapat hubungan yang bermakna antara umur dengan prilaku pencegahan Covid-19 dengan nilai $P=1,4 .{ }^{15}$ 
Pada penelitian ini didapatkan mayoritas responden berumur 18-40 tahun dengan prilaku pencegahan Covid yang baik. Hal ini diduga dikarenakan responden merasa beresiko terkena penyakit Covid-19 hal ini dikarena penyakit ini dapat menyerang segala aspek usia baik usia muda sampai usia tua, oleh karena itu masyarakat dengan segala aspek usia melakukan prilaku pencegahan terhadap Covid-19 untuk mencegah terpapar penyakit Covid-19. Secara psikologis seseorang akan banyak melakukan tindakan pencegahan karena merasa lebih rentan terhadap penyakit. ${ }^{16}$

Pendidikan mempengaruhi proses belajar, makin tinggi pendidikan seseorang makin mudah orang tersebut untuk menerima informasi. ${ }^{17}$ tingkat pendidikan dapat mempengaruhi partisipasi dan peran serta masyarakat dalam berperilaku. Seseorang yang menerima pendidikan yang lebih baik atau tinggi, biasanya akan lebih mampu berpikir secara obyektif dan rasional dengan berpikir secara rasional, maka seseorang akan lebih mudah menerima hal - hal baru yang dianggap menguntungkan bagi dirinya. ${ }^{18}$ Seseorang dengan pendidikan tinggi, maka semakin luas pengetahuannya dalam menerima informasi dalam hal ini tentang pencegahan Covid-19.

Pada penelitian ini diperoleh hasil bahwa tidak ada hubungan yang bermakna antara pendidikan dengan perilaku pencegahan Covid-19 dengan nilai $P=0,203$ $(P>0,05)$. Hal tidak sejalan dengan penelitian yang didaptkan dari penelitian Lenny Gannika dkk, penelitian tersebut menyatakan bahwa terdapat hubungan yang bermakna antara pendidikan dengan prilaku pencegahan Covid-19 dengan nilai $\mathrm{P}=0,00 .{ }^{19}$

Ketidaksesuaian hasil dari penelitian ini dengan penelitian sebelumnya kemungkinan disebabkan oleh perbedaan karakteristik responden yang dijadikan sampel dalam penelitian. Selain itu, ketidakbermaknaan antara tingkat pendidikan dengan perilaku pencegahan Covid-19 dikarenakan pendidikan pada dasarnya tidak hanya dapat diperoleh dari bangku sekolah (formal) tetapi juga di lingkungan keluarga, masyarakat, dan dari media lainnya (majalah, berita).

Pengetahuan adalah apa yang diketahui oleh seseorang tentang sesuatu hal yang didapat secara formal maupun informal. ${ }^{20}$ Menurut teori Lawrence Green menjelaskan bahwa pengetahuan merupakan faktor awal dari suatu perilaku yang diharapkan dan pada umumnya berkorelasi positif dengan perilaku. Berdasarkan tingkatan tahu, memahami, mengaplikasikan, analisa, sintesa, dan evaluasi yang nantinya akan mempengaruhi perilaku kesehatan yang dilakukan. ${ }^{20}$ Sehingga tingkat pengetahuan mencakup apa saja yang seharusnya dilakukan dan yang tidak dilakukan sebagai upaya pencegahan Covid-19. Mereka yang memiliki tingkat pengetahuan yang kurang, akan lebih mudah terkana Covid-19 dikarenakan mereka kurang mengerti hal apa saja yang berhubungan dan yang dapat mencegah penularan Covid-19. Dengan tingkat pengetahuan semakin baik maka kemungkinan untuk terjadinya Covid-19 semakin kecil. 
Pengetahuan tentang penyakit

Covid-19 merupakan hal yang sangat penting agar tidak menimbulkan peningkatan jumlah kasus penyakit Covid19. Pengetahuan pasien Covid-19 dapat diartikan sebagai hasil tahu dari pasien mengenai penyakitnya, memahami penyakitnya, cara pencegahan, pengobatan dan komplikasinya. ${ }^{21}$ Pengetahuan memegang peranan penting dalam penentuan perilaku yang utuh karena pengetahuan akan membentuk kepercayaan yang selanjutnya dalam mempersepsikan kenyataan, memberikan dasar bagi pengambilan keputusan dan menentukan perilaku terhadap objek tertentu sehingga akan mempengaruhi seseorang dalam berperilaku. ${ }^{22}$

Pada penelitian ini diperoleh hasil bahwa tidak ada hubungan yang bermakna antara pengetahuan dengan prilaku pencegahan Covid-19 dengan nilai $P$ sebesar 0,320 $(P>0,05)$. Hal tidak sejalan dengan penelitian yang didaptkan dari penelitian Mujiburrahman dkk, penelitian tersebut menyatakan bahwa terdapat hubungan yang bermakna antara pengetahuan dengan prilaku pencegahan Covid-19 dengan nilai $P=0,001 .{ }^{23}$ Tidak ada hubungannya dalam penelitian ini diduga dikarenakan responden hanya sekedar mengetahui mengenai pencegahan Covid-19, namun tidak mengaplikasikan dalam bentuk tindakan. Hal ini sesuai teori Bloom yang menyatakan bahwa domain pengetahuan berawal dari tahu hingga domain aplikasi. ${ }^{20}$ Domain tahu hanya mengetahui tentang pencegahan Covid-19, namun belum dapat menerapkannya dalam perilaku ketika praktik.

Sikap merupakan suatu tindakan atau aktivitas, akan tetapi masih merupakan predisposisi tindakan suatu perilaku. Sikap seseorang akan mempengaruhi perilaku kesehatan, sikap positif seseorang akan menghasilkan perilaku kesehatan yang positif pula. Sedangkan sikap yang negatif akan menghasilkan perilaku kesehatan yang negatif pula. Sikap positif adalah suatu sikap yang sesuai dengan nilai-nilai kesehatan yang berlaku, sedangkan sikap negatif adalah sikap yang tidak sesuai dengan nilainilai kesehatan yang berlaku. Sikap positif disini adalah sudah benar dalam bersikap tentang hal-hal apa saja yang seharusnya dilakukan dalam melakukan pencegahn terhadap Covid-19. Sedangkan sikap negatif tentang hal-hal apa saja yang tidak seharusnya dilakukan dalam pencegahannya Covid-19. Sikap yang positif dari responden kemungkinan disebabkan pengalaman responden yang banyak dan pembentukan sikap yang baik sehingga melahirkan pola pikir yang baik, serta keyakinan dan emosi yang baik . ${ }^{20}$

Pada penelitian ini diperoleh hasil bahwa tidak ada hubungan yang bermakna antara sikap dengan prilaku pencegahan covid-19 dengan nilai $P$ sebesar 0,466 $(P>0,05)$. Hal ini sejalan dengan penelitian Ramadhani.f dkk, penelitian tersebut mendaptakan hasil bahwa tidak terdapat hubungan yang bermakna antara sikap dengan perilaku pencegahan Covid-19 dengan nilai $p=0,874 .{ }^{24}$ Sikap merupakan suatu reaksi menerima atau menolak pesan informasi yang diterima oleh akal maka jika 
informasi yang diterima tersebut dipahami maka belum tentu informasi tersebut dilaksanakan. ${ }^{25}$

Hal ini memperkuat dugaan mengenai hubungan pengetahuan dengan prilaku jika responden memendapatkan informasi mengenai pencegahan Covid-19 maka responden memiliki pengetahuan mengenai pencegahan Covid-19 jika pengetahuan ini di pahami maka belum tentu pengetahun atau informasi tersebut dilaksanakan. Walaupun dalam penelitian ini prilaku responden dalam pencegahan Covid-19 baik namun kebenaran data tergantung kejujuran dari responden masing-masing, pada penelitian ini hanya sebatas pengisian kuesioner dan tidak melakukan observasi lebih lanjut.

\section{KESIMPULAN}

Tidak terdapat hubungan bermakna antara Usia, Pendidikan, Pengetahuan dan Sikap dengan Perilaku pencegahan Covid19 Masyarakat pada wilayah kerja Puskesmas Kenali Besar Kecamatan Alam Barajo. Diperlukan penelitian secara kualitatif untuk mengetahui akar masalah yang tidak bisa dinilai dari penelitian kuantitatif.

\section{DAFTAR PUSTAKA}

1. Sudarsa IW. Pembedahan Kanker di Masa Pandemi COVID-19. JBN (Jurnal Bedah Nasional). 2020;4(1):1.

2. Beniac DR, Andonov A, Grudeski E, Booth TF. Architecture of the SARS coronavirus prefusion spike. Nat Struct Mol Biol. 2006;13(8):751-2.

3. Gulati G, Dunne CP, Kelly BD. Prisons and the COVID-19 Pandemic. Ir J Psychol Med. 2020;1-2.

4. World Health Organization. Coronavirus disease 2019 (COVID-19) Situation Report - 68.[Internet]. 2020 [11Desember2020]Availablefrom:https://www.who.int/emergencies/diseases/novel-coronavirus2019/situation-reports.

5. Hartati R, Imbiri MJ, Setiani D, Teknologi J, Medis L, Kemenkes P. Gambaran Pengetahuan Mahasiswa Tentang Infeksi Covid-19. 2020;12:7-13.

6. Kementerian Kesehatan Republik Indonesia. Keputusan Menteri Kesehatan Republik Indonesia Nomor HK.01.07/Menkes/722/2020 tentang Standar Profesi Penata Anestesi. Kementrian Kesehat Republik Indones. 2020;

7. Pemprov Jambi. Media Center Gugus Tugas Penanganan Covid-19 11 Desember 2020.[internet].2020.[11Desember 2020].Available.From:http//corona.jambiprov.go.id/V2/

8. Pemkot Jambi. Pusat Informasi Covid-19 Data Terbaru 14 Desember 2020.[internet].2020. [14 Desember2020].Availabe.From:http://Covid19.Jambikota.go.id.

9. Usman S, Budi S, Nur Adkhana Sari D. Pengetahuan Dan Sikap Mahasiswa Kesehatan Tentang Pencegahan Covid-19 Di Indonesia. / J Ilmu Keperawatan dan Kebidanan [Internet]. 2020;11(2):4104. Tersedia pada: Pengetahuan Dan Sikap Mahasiswa Kesehatan Tentang Pencegahan Covid-19 Di Indonesia

10. Hafandi Z, Ariyanti R. Hubungan Pengetahuan tentang Covid-19 dengan Kepatuhan Physical Distancing di Tarakan. J Kebidanan Mutiara Mahakam. 2020;8(2):102-11.

11. Moudy J, Syakurah RA. Pengetahuan terkait usaha pencegahan Coronavirus Disease (COVID-19) di Indonesia. Higeia J Public Heal Res Dev. 2020;4(3):333-46.

12. Darmawan AAKN. Faktor-faktor yang mempengaruhi prilaku kunjungan masyarakat terhadap pemanfaatan pelayanan posyandu di desa pemucutan kelod kecamatan denpasar barat. J.Dunia Kesehatan.2015;5(2);29-39. 
13. Caramelo, F., Ferreira, N., \& Oliveiros, B. Estimation of risk factors for COVID-19 mortality-preliminary results. MedRxiv, 2020.

14. Kementrian Kesehtan Republik Indonesia. Hindarai lansia dari Covid-19.[internet].2021.[9 Februari 2021].avalabe.from: http://www.padk.kemkes.go.id/article/read/2020/04/23/21/hindari-lansia-daricovid-19.html

15. Prihati Dr,Wirawati MK, Supriyanti E. analisis Pengetahuan dan Prilaku Masyarakat di Kelurahan Baru Kota Waringin Barat Tentang Covid-19. J Nursing Malahayati.2020;2(4):780-90

16. Sarafino, E. P. Health psychology, biopsychosocial interaction. New York: Jhon Wiley \& Sons, Inc. 2004

17. Wawan, A., \& Dewi. Teori dan pengukuran pengetahuan dan perilaku manusia. Yogyakarta: Nuha Medika. 2010

18. Notoatmodjo. Metodologi Penelitian Kesehatan. Jakarta: PT Rineka Cipta; 2010;

19. Gannika L, Sembiring E. Tingkat Pengetahuan dan Perilaku Pencegahan Coronavirus Disease 2019 (COVID-19) Pada Masyarakat Sulawesi Utara. J Keperawatan. 2020;16(2):83-9.

20. Notoatmodjo S. IImu Kesehatan Masyarakat .Jakarta: Rineka Cipta.2003.

21. Mona N. Konsep Isolasi Dalam Jaringan Sosial Untuk Meminimalisasi Efek Contagious (Kasus Penyebaran Virus Corona Di Indonesia). J Sos Hum Terap. 2020;2(2):117-25.

22. Novita, dkk. Tingkat Pengetahuan Tentang TB Paru Mempengaruhi Penggunaan Masker Di Ruang Paru Rumkital Dr. Ramelan Surabaya. Jurnal IImiah Kesehatan.2014; Vol 7. No. 12.

23. Mujiburrahman, Riyadi ME, Ningsih MU. Pengetahuan Berhubungan Dengan Peningktan Prilaku Pencegahan COVID-19 di Masyarakat. J Kep Terpadu.2020 Oktober;2(2);130-140.

24. Ramadhani F, Gizi PS, Masyarakat FK, Gorontalo U. Pengetahuan Berkorelasi Positif dengan Perilaku Pencegahan Covid - 19 pada Mahasiswa di Gorontalo. 2020;2(3):108-17.

25. Rachman LA, Yulianto FA, Djojosugito MA, Andarini MY, Djajakusumah TS. Hubungan Pengetahuan dan Sikap terhadap Perilaku Penggunaan Alat Pelindung Diri di PT Sarandi Karya Nugraha Sukabumi. J Integr Kesehat Sains. 2020;2(2):154-9. 